\title{
Frequency grid-a simple tool for measuring grassland establishment
}

\author{
KENNETH P. VOGEL AND ROBERT A. MASTERS
}

Authors are Research Geneticist and Rangeland Scientist, respectively, USDA-ARS, 344 Keim Hall, Univ. of Nebraska, P.O. Box 830937, Lincoln, Nebr. 68583-0937. Research is from USDA-ARS and University of Nebraska cooperative forage and range research programs affiliated with the Agronomy Department and the Center for Grassland Studies, University of Nebraska.

*Corresponding author. (Email:kpv@unlserve.unl.edu).

\begin{abstract}
Simple, reliable tools are needed by land managers to quantify establishment success when seeding or re-seeding pastures or rangeland. A frequency grid was designed to measure seedling or plant establishment success for a single species, mixtures of species, or single species of a mixture. The frequency grid is a metal frame containing 25 squares $(5 \times 5)$ or cells and can be made from concrete reinforcing sheets that have $15 \times 15 \mathrm{~cm}$ squares. When used, the frequency grid is either randomly or systematically placed within a seeded area. The number of cells containing 1 or more seeded plants are counted. The grid is then flipped, end-over-end, and the counts are repeated. The process is repeated until a total of $\mathbf{1 0 0}$ cells have been counted per sampling location within a seeded area. Counts can be directly converted into frequency of occurrence or stand percentages by dividing the number of cells that contain a seeded plant by 100 . The process can be repeated at several locations within a seeded area to characterize establishment success. Multiplying frequency of occurrence percentages by 0.4 provides a conservative estimate of plant density (plants $\mathrm{m}^{-2}$ ). A single measurement of 100 frequency grid cells can be taken in less than 5 minutes. The frequency grid is inexpensive to make, requires minimal training, permits rapid measurements, and provides a meaningful estimate of plant density. The frequency grid has been used to document herbicide efficacy and seeding rates for use in grassland establishment in the central Great Plains and should be easily adaptable for use in other geographic regions.
\end{abstract}

Key Words: planting, rangeland, pasture, plant density, seedling counts

Millions of hectares of land have been seeded to grasslands in the Great Plains and other western states. Additional land will likely be seeded in the future to convert marginal cropland to grasslands, upgrade existing seeded grasslands, and to restore degraded rangeland invaded by noxious weeds or damaged by fires. In addition, millions of hectares of pastures are periodically seeded in humid grassland areas worldwide. After each establishment attempt, the questions that managers must answer include: Was the seeding successful? Is the stand adequate for the intend-

Journal series no. 13201, Nebraska Agricultural Experiment Station.

Manuscript accepted 29 Dec. 2000.

\section{Resumen}

Los manejadores de tierras necesitan herramientas simples y confiables para cuantificar el éxito del establecimiento cuando se siembran o resiembran praderas o pastizales. Se diseño una cuadricula de frecuencia para medir el éxito del establecimiento de plántulas o plantas de una sola especie, mezclas de especies o una sola especie en una mezcla. La cuadrícula de frecuencia es un marco de metal que contiene 25 cuadros $(5 \times 5)$ o celdas y pueden ser hechas hojas para reforzar concreto que tienen cuadros de $15 \times 15$. Cuando se utiliza, la cuadrícula de frecuencia es colocada aleatoriamente o sistemáticamente dentro del área sembrada. Se cuenta el número de celdas que contienen 1 o más plantas sembradas. Entonces la cuadrícula se lanza y los conteos se repiten. Este proceso es repetido hasta que se ha contado un total de 100 celdas por localidad de muestreo en el área sembrada. Los conteos pueden ser directamente convertidos a frecuencias de ocurrencia o porcentajes dividiendo el número de celdas conteniendo una planta sembradas sobre 100 . El proceso puede ser repetido en varias localidades dentro del área sembrada para caracterizar el éxito del establecimiento. La multiplicación de los porcentajes de frecuencia de ocurrencia por 0.4 provee una estimación conservadora de la densidad de plantas (plantas $\mathrm{m}^{-2}$ ). Una sola medición de 100 celdas de la cuadrícula de frecuencia puede ser tomada en menos de 5 minutos. La construcción de la cuadrícula de frecuencia es barata, requiere de entrenamiento mínimo, permite medidas rápidas y provee una estimación significativa de la densidad de plantas. La cuadrícula de frecuencia ha sido utilizada para documentar la eficacia de herbicidas y dosis de siembra para su uso en el establecimiento de pastizales en las Grandes Planicies centrales y debe ser fácilmente adaptable para su uso en otras regiones geográficas.

ed purpose? If not, do only portions of the seeded area need to be planted again? Because of these questions, managers need tools to quantify the success of grassland plantings and not be forced to rely on visual evaluations.

The goal of all grassland re-vegetation is to obtain an acceptable number of established plants of the desired, seeded species per unit of land (i.e., density) which is often expressed as plants $\mathrm{m}^{-2}$. To be of most value, the plant density measurement also should provide an estimate of plant distribution over the unit area. Methods that have been developed to determine plant density and species composition in grasslands include density per quad- 
rant, 10-point frame, line point, line intercept, and visual estimates (Cook and Stubbendieck 1986, Bonham 1989). Visual estimates can vary widely depending on the experience and qualifications of the person making the estimate and can be unreliable. The other methods have been widely used in research but require a certain level of training and experience plus they are physically demanding because time is spent on one's hands and knees or bent over. The 10-point frame, line point, and line intercept methods do not provide direct measurement of plant density. Plant density per quadrant does provide direct measurement of plants per unit area but requires a considerable amount of skilled labor since all plants in a quadrant are usually identified and counted.

Here we describe a simple tool, the frequency grid, that we have used in our research to study seeding rates, herbicide efficacy, and rangeland and pasture improvement strategies. Frequency is the presence or absence in a sampling unit calculated as a percentage (Cook and Stubbendieck 1986, Bonham 1989). Advantages associated with this variable are that it is quick and easy to measure since only the presence or absence (yes or no) of a plant is recorded and it combines density and dispersion characteristics.

\section{Materials and Methods}

The frequency grid is a metal frame containing 25 squares $(5 \times 5)$ or cells and can be made from concrete reinforcing sheets that have $15 \times 15 \mathrm{~cm}$ squares (Fig. $1)$. We recently purchased a concrete rebar sheet of 4 gauge steel measuring $2.4 \times 6.1$ $\mathrm{m}$ with $15 \mathrm{~cm}$ squares for US $\$ 35.00$. We cut 12 grids from the single sheet for a materials cost of $\$ 3.00$ per grid. The grids can be used as is or can be painted to make the bars within the grid more distinctive for field use.

When used, the frequency grid is either randomly or systematically placed within a seeded area. The number of cells containing 1 or more seeded plants is counted. The grid is then flipped, end-over-end, and the counts are repeated. The process is repeated 3 times until a total of 100 cells have been counted per sampling location within a seeded area. Counts can be directly converted into frequency of occurrence or stand percentages by dividing the number of cells that contain a seeded plant by 100. Systematic placement can be used on small plots so that similar areas of each plot are measured while random place- ment is more suitable for larger areas. The process can be repeated at several locations within a seeded area to characterize establishment success of the entire area. Frequencies can be determined for single species by obtaining separate counts by species. Frequency measurements can be made after seedling emergence, at the end of the growing season the establishment year, following spring green up the year after establishment, or at several different times. The person making the counts has to be able to identify the seeded species. Since the total area covered by 4 grid units is $2.25 \mathrm{~m}^{2}$, multiplying frequency of occurrence percentages by 0.4 provides a conservative estimate of plants per $\mathrm{m}^{2}(1$ $\mathrm{m}^{2} / 2.25 \mathrm{~m}^{2}=0.44$ or approximately 0.4 ).

In the example shown in Fig. 1A, 18 cells have a seeded grass plant and assuming that when flipped end-over-end and counted 3 more times (not shown), the number of cells with 1 or more seeded grass plants was 17,15 , and 20 for a total
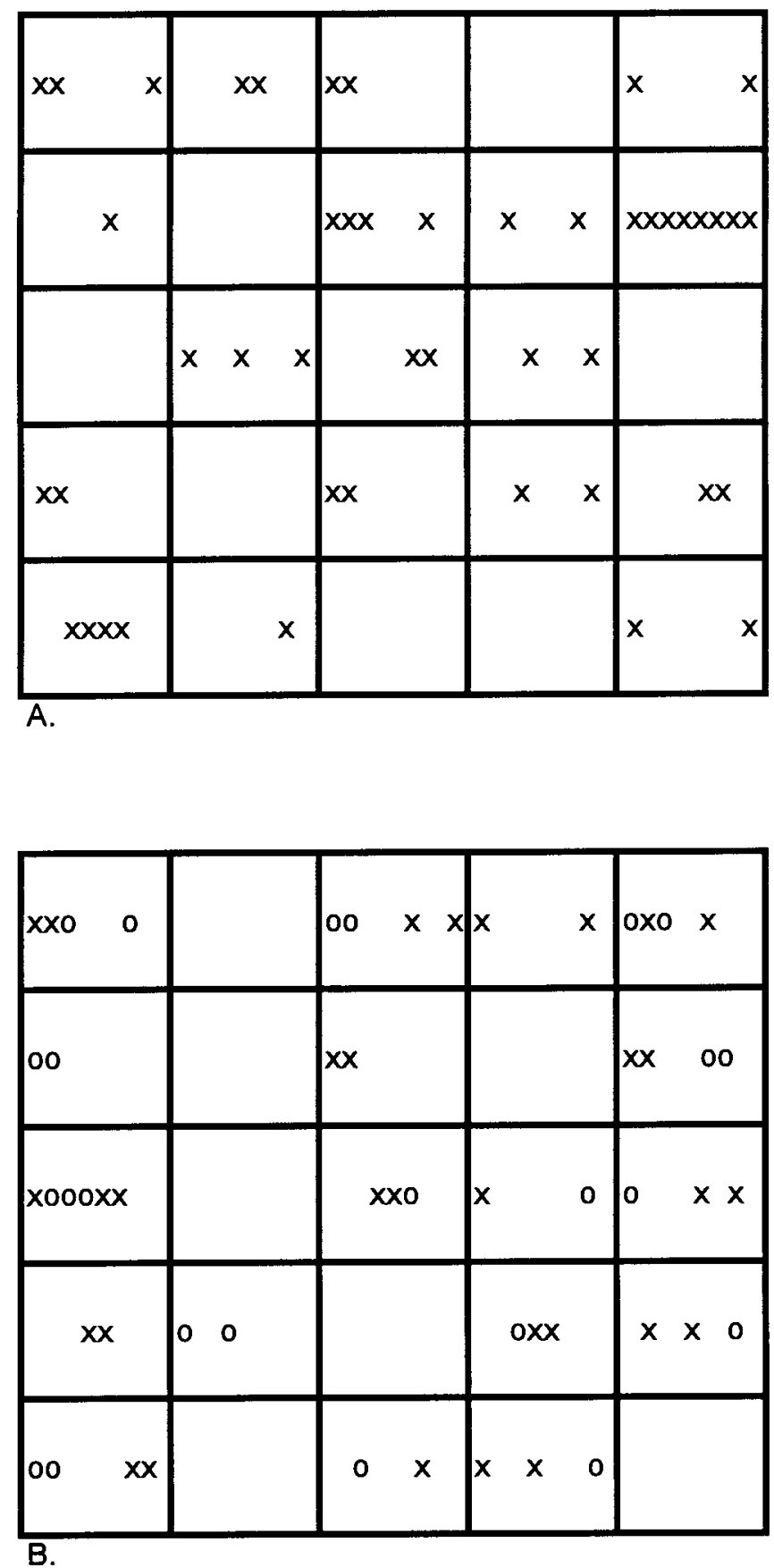

Fig. 1. Frequency grid examples where $x=$ grass plant and $o=$ forb or legume. 
of 70. Frequency of occurrence would be $70 / 100$ or $70 \%$ which when multiplied by 0.4 would give an estimate of 28 plants $\mathrm{m}^{-2}$. In the grass-forb seeding example shown in Fig. 1B, the number of cells with 1 or more seeded grass plants is 16 while cells with seeded forbs is 15 . Assuming that the grid is flipped end-over-end and counted three more times (not shown), the number of cells with seeded grasses was 18, 20, and 14 for a total of 68 while the number of forbs was 12, 14, and 19 for a total of 60 . The frequency for grasses and forbs would be 68 and $60 \%$, respectively. Density of grasses and forbs would be conservatively estimated as 27 and 24 plants $\mathrm{m}^{-2}$, respectively. Total plant frequency of occurrence could also be determined by counting the number of cells that contained either a seeded grass or forb.

\section{Results and Discussion}

The frequency grid is inexpensive, easy to make and use, and requires no "knee time". Once trained to identify the planted species, it is fast, reliable, and accurate. Stand frequencies can be routinely obtained on a single plot in less than 5 minutes. The Least Significant Differences or LSD's for stand frequency from our research trials are often about 10 to $15 \%$ (Vogel 1987, Masters et al. 1996, Masters 1997, Masters and Nissan 1998). The same level of reliability has been used to obtain stand frequencies in pastures (Bauer et al. 1996). This technique can be used to monitor establishment of single or multiple species. The success rate for individual species within a mixture can also be determined.

The frequency grid is essentially a quadrant that has been subdivided into 25 cells. Its use is based on the premise that, in establishment of grasslands, there are threshold densities of plants in a quadrant and that it is not necessary to count every plant. Multiplying the frequency of occurrence by 0.4 provides a conservative estimate of the number of plants $\mathrm{m}^{-2}$ because only a single count is made per grid cell even though a cell may contain several plants. In the Great Plains, it is possible to use this conservative estimate of plant density to determine if a planting is successful. Cornelius (1944) reported that 20 established plants $\mathrm{m}^{-2}$ would give a stand similar to that of native Great Plains prairie. Launchbaugh (1966), in a stand establishment survey of over 3,000 grass seedings in the Great Plains, classified plantings with 10 or more seedlings $\mathrm{m}^{-2}$ as good stands. In a designed study at Hays, Kan., Launchbaugh and Owensby (1970) determined that establishment-year densities of 20 to 30 plants $\mathrm{m}^{-2}$ of native grasses, including big bluestem (Andropogon gerardii Vitman) and switchgrass (Panicum virgatum L.), were generally ready to be grazed the following year.

Research by Vogel (1987) and Masters (1997) using the frequency grid demonstrated that switchgrass or big bluestem plots with a frequency of occurrence of $40 \%$ or more $\left(16\right.$ plants $\left.\mathrm{m}^{-2}\right)$ did not differ in forage yield the first or second year after establishment. In these studies, frequency of occurrence ranged from 27 to $94 \%$. Plots with initial frequencies as low as $30 \%$ (12 plants $\left.\mathrm{m}^{-2}\right)$ produced lower yields the first year after establishment but, by the second year after establishment, yields were equivalent to plots with higher initial frequencies of occurrence. These results, when combined with the previous research by Cornelius (1944), Launchbaugh (1966) and Launchbaugh and Owensby (1970), indicate that in the Great Plains, frequency grid values of $50 \%$ or higher (20 or more plants $\mathrm{m}^{-2}$ ) would be classified as fully successful stands, frequencies of 25 (10 plants $\left.\mathrm{m}^{-2}\right)$ to $50 \%$ would indicate marginal to adequate stands while stands of less than $25 \%$ could be regarded as requiring partial re-establishment or unsuccessful.

We have used the frequency grid to determine seeding rates that are needed to establish grasses when pre- or post-emergence herbicide treatments are used to control weeds (Vogel 1987, Masters 1997) and to assess rangeland and pasture improvement strategies (Masters et al. 1996, Masters and Nissan 1998). Data derived from these studies has been used to register herbicides for use in non-cropland, rangeland, and pastures. Grassland plantings can be made using drills that vary in distance between the seeding units, by broadcasting, or several other methods of seed application. Since the frequency grid measures frequency of occurrence on a unit area basis, it can be used to measure establishment for any planting method.

Although, we have used the frequency grid only on Great Plains grasslands, it should be readily adaptable for use in other geographical regions. Research will be needed to correlate frequencies of occurrence to other methods that have been used to measure stand establishment and grassland productivity following establishment. In summary, the frequency grid is a reliable, accurate, rapid, and inexpensive method that can be used to quantify the success of a grassland planting.

\section{Literature Cited}

Bauer, D., K.P. Vogel, and L.E. Moser. 1996. Grazing evaluation of cool-season grasses in the Nebraska Sandhills in replicated ranch trials. Soc. Range Manage. Annu. Meeting Abst. p. 6-7.

Bonham, C.D. 1989. Measurements for terrestrial vegetation. John Wiley \& Sons, N.Y.

Cook, C.W. and J. Stubbendieck. 1986. Range research: Basic problems and techniques. Soc. Range Manage. Denver, Colo.

Cornelius, D.R. 1944. Revegetation in the tallgrass prairie region. J. Amer. Soc. Agron. 36:393-400.

Launchbaugh, J.L. 1966. A stand establishment survey of grass plantings in the Great Plains. Nebraska Agric. Exp. Stn. Great Plains Counc. Publ. 23.

Launchbaugh, J.L. and C.E. Owensby. 1970. Seeding rate and first-year stand relationships for six native grasses. J. Range Manage. 23:424-417.

Masters, R.A. 1997. Influence of seeding rate on big bluestem establishment with herbicides. Agron. J. 89:947-951.

Masters, R.A. and S.J. Nissen. 1998. Revegetating leafy spurge (Euphorbia esula L.)-infested grasslands with native tallgrasses. Weed Technol. 12:381-390.

Masters, R.A., S.J. Nissen, R.E. Gaussoin, D.D. Beran, and R.N. Stougaard. 1996. Imidazolinone herbicides improve restoration of Great Plains grasslands. Weed Technol. 10:392-403.

Vogel, K.P. 1987. Seeding rates for establishing big bluestem and switchgrass with preemergence atrazine applications. Agron. J. 79:509-512. 